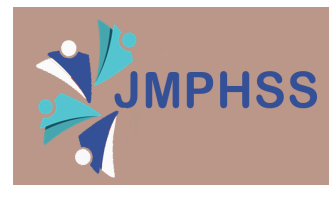

Journal of Management Practices, Humanities and Social Sciences

Vol 4 Issue 1 pp. 16-20

https://doi.org/10.33152/jmphss-4.1.4

\title{
ORIGINAL CONTRIBUTION \\ The Strategies for Addressing Main Characters in Isan Literature: A Case Study of Khulu-Nang Ua
}

\author{
Itsarate Dolphen * \\ Khon Kaen University, Khon Kaen, Thailand
}

\begin{abstract}
This paper aims at exploring the strategies for addressing main characters in the Northeastern Thai literature of Khulu-Nang Ua. KhuluNang Ua is one of the most famous Isan literature in Northeast Thailand. This literature belongs to a tradition of tragic romances as Romeo and Juliet but in Isan version. The plot is based on an Isan folktale written in verse without any evidence of the writer but revised by Preecha Phinthong. Besides having good plot and using beautiful words to compose this tragic story, the strategies the writer used to address the main characters, Khulu and Nang Ua, are remarkable. Only the main characters, Khula (the hero) and Nang Ua (the heroine) are explored. This paper used quantitative methodology by undertaking a content analysis to collect data from the the Northeastern Thai literature. The findings reveal that there are two main strategies for addressing main characters in Khula-Nang Ua which are 1) direct address and 2) indirect address. For the direct address, there are four sub-strategies to be used as follows: 1) name, 2) name title + name, 3) name title + name + modifier, and 4) name + modifier. As for the indirect address, there are four sub-strategies as well that the writer used them to address main characters in this story as follows: 1) metaphorical words, 2) pronouns, 3) name title, and 4) name title + modifier. It was found that the metaphorical words was often used as the main strategies to address the characters, especially for Nang Ua. This is because many metaphorical words were found and used diversely.
\end{abstract}

Index Terms - Strategies, Address Term, Main Characters, Isan Literature, Khulu-Nang Ua .

Received: 9 January 2020; Accepted: 29 May 2020; Published: 28 June 2020

\section{Introduction}

Khulu-Nang Ua is one of the famous Isan literature in Northeast Thailand (Thamwat, 1999; Phiuthong, 2002). Phiuthong (2002) mentioned that this folk literature were composed nicely. This story provides both entertainment and knowledge. Phiuthong (2002) also stated that in terms of socio-culture such as in aspect of making proposal for marriage, Thai Isan people have culture of the making proposal for marriage when a man and woman agreed to live together in which the man must arrange for his elder relatives to go to the parents of the woman with tribute.

According to Bevington (2019), Romeo and Juliet is about two powerful families erupts into bloodshed. And with its similarity and tragic plot, Khulu-Nang Ua is deserved as a tradition of tragic romances as Romeo and Juliet but in Isan version.

Besides the plot and beautiful words of composing, the strategies for addressing main characters are very interesting. The writer has many different strategies for choosing words to refer to a protagonist. It is believed that different strategies are supposed to show different meanings and characteristics of the main characters.

Therefore, the objective of this paper is to explore the strategies for addressing main characters in the Northeastern Thai literature of KhuluNang Ua. The main characters in this paper are referred to the hero and heroine which are Khulu and Nang Ua respectively.

Significance of the study

To understand how the writer creatively used the words addressing the main characters directly and indirectly in a narrative plays an important attitude of the writer himself towards the characters and the plot. We can understand vividly how the writer thinking about the characters through the strategies the writer using the words referring to the main characters. The character's name might be used directly referring to the main characters or metaphorical words are the other forms the writer preferred. This is why this study is significant to study in terms of both language and literature.

\section{Scope and Conceptual Framework of the Study}

This paper used quantitative methodology (Williamson et al., 2018) by undertaking a content analysis to collect data from the the Northeastern Thai literature. The focus data in this paper was Khulu-Nang Ua which is one of the most famous Isan literature in Northeast Thailand. Only the main characters namely Khulu (the hero) and Nang Ua (the heroine) are explored. The address terms were collected separately regarding differ-

\footnotetext{
${ }^{*}$ Email: itsdol@kku.ac.th
} 
ent main characters and then comparatively analyzed by content analysis as well as semantic approach. The data collection was divided into two groups regarding the two main characters as follows, 1) names and words addressing to the hero, 2) names and words addressing to the heroine. For analyzing data, the structure of word formation was proposed as a method to classify the strategies for addressing the main character with the semantic approach. The conceptual framework of a study can be shown in Fig. 1.

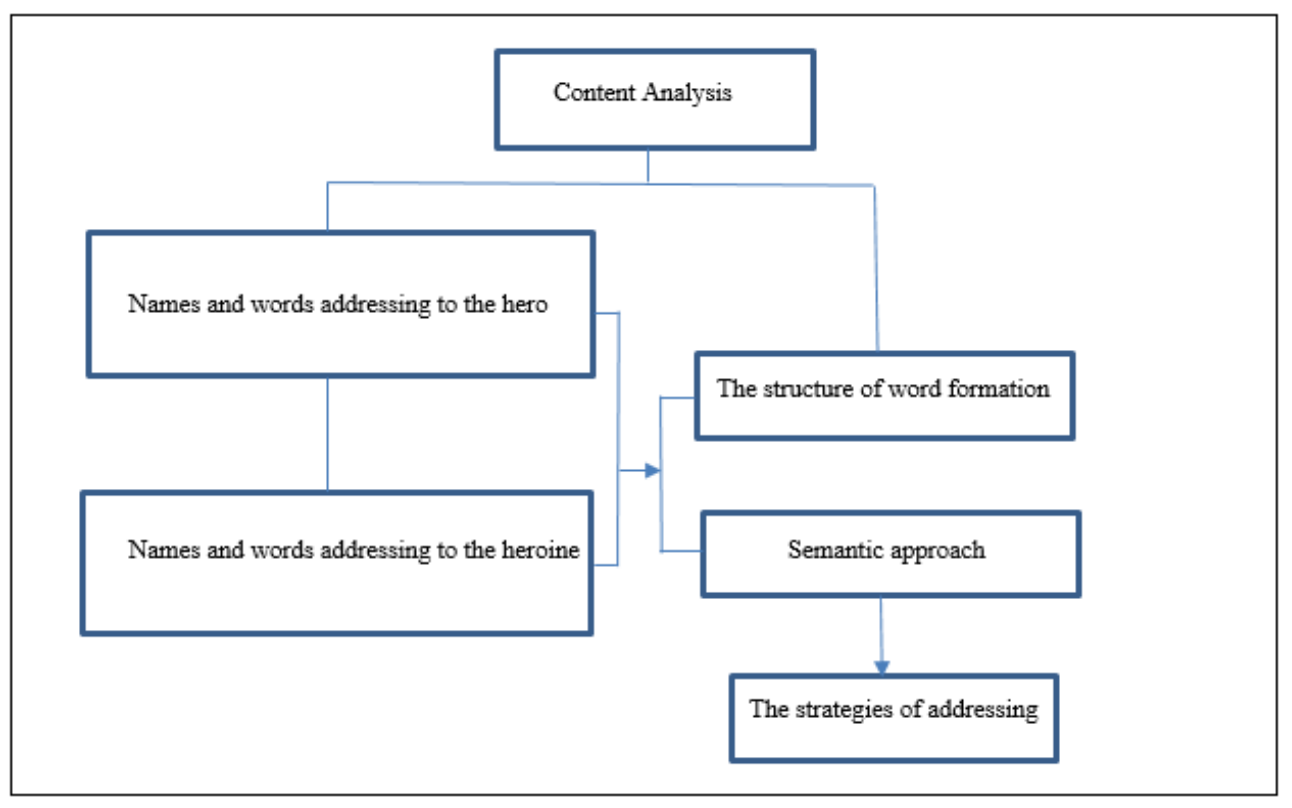

Fig. 1. The conceptual framework

\section{Methodology}

This study is a qualitative research study based on a content analysis. A breakdown of the method into steps is as follows:

1. Review the theoretical framework of using content analysis and semantic approach related to word structure.

2. Collect research data from the Northeastern literature of KhuluNang Ua.

3. Identify structure of forming words to refer to the main characters which will be analyzed as the strategies for addressing main characters in the Northeastern Thai literature of Khulu-Nang Ua.

4. Compare strategies of using words to address to the main characters (protagonists), Khulu and Nang Ua under semantic approach.

\section{Khulu-Nang Ua: Romeo and Juliet in Isan Version}

If Romeo and Juliet is a famous tragedy written by William Shakespheare in the Western side, Khulu-Nang Ua is also a famous tragedy in Isan version. As Khulu-Namg Ua is a folk literature, there is no any evidence to tell that who is the writer of this story. It was written and told from generation to generation. Punnotok (1982) mentioned that the writer of Khulu-Nang Ua did not tell his name when this literature is written. The writer just informed that this story was composed in the evening. What we know about the writer is that the writer is a monk.

The manuscript of Khulu-Nang Ua was written in Dhamma alphabet. It belongs to Nam Kham Daeng Temple, Muangsamsip, Ubon Ratchathani Province. This folk literature was revised by Phiuthong (2002).

The plot of Khulu-Nang Ua shares a similarity to Romeo and Juliet that boy and girl kill themselves at the end of the story. In terms of plot, the classic story of boy meets girl in Romeo and Juliet is different from Khulu-Nang Ua just the boy in Khulu-Nang Ua does not kill girl's cousin. The similar plot is that girl's family hates boy's family and then they kill themselves
(Shakespeare Birthplace Trust, n.d.)

According to Wisaphan (2006), a tragedy literature reflects human's suffering and the death of the characters in Khulu-Nang Ua is the result of behavior and usual practice of the character. Khulu and Nang Ua are in ruling class people. Their family used to have good relationship. The conflict occurred before Khulu and Nang Ua were not born. Nang Ua commits suiside because her mother hates Khulu's family. The mother does not want her daughter to marry with the stingy family like Khulu's family.Then she forces her lovely daughter to marry with an old rich man. Nang Ua feels sad and does not want to marry with the old man because she already has her own beloved. Then at night before a wedding ceremony, Nang Ua hangs herself under a tree in the garden. When Khulu heard that Nang Ua was dead, he then stabs his neck with a knife. Both families regret it and then return back to have a good relation ship after the funeral of their own son and daughter.

Prasertsang (2018) stated the funeral ceremony in Khulu-Nang Ua reflected the characteristics of the great honorable funeral of the ruling class people.

\section{Results}

The research data were analyzed by using content analysis to collect words used to address the main characters (protagonists), Khulu and Nang Ua respectively. The result revealed that there are totally 82 different words to be used to refer to the main character, 24 words referring to Khulu and 58 words belonging to Nang Ua. The results were clarified as follows:

There are two main strategies for addressing main characters in KhuluNang Ua which are 1) direct address, and 2) indirect address.

Direct address refers to the address term forming with the name of character, whereas indirect address focusing on a metaphorical technique 
and a word formation of head-modifier structure. The followings are some examples of mentioned strategies.

\section{Direct address}

For the direct address, there are four sub-strategies to be used as follows:

The strateg of using name: This strategy is simply used by just mentioning the name of the protagonist that can be shown below.

1) ขูลู khuuluu 'Khulu'

\section{วันหนึ่งแม่ก็่ออออดต้าน}

wan nueng mae kor or-ort taan 'one day, the mother spoke

The word ขูลู 'Khulu' is a name of the hero in Khulu-Nang Ua. The writer used this name exactly addressing for Khulu. It was found that this strategy is used for Khulu only. Based on research data, the name of the heroine : อั้ว ua 'Ua' is not found to be used alone in the story. It was also found that the writer used a kinship term $\overrightarrow{\text { w }}$ phii 'elder brother' to address the protagonist, Khulu, as พี่ขูลู phii khulu 'elder brother Khulu' to signify that Khulu is older than Nang Ua. This kinship term is added in front of the name of the protagonist.

The strategy of using name title+name:

2) ท้าวขูลู thaw khulu 'Mister Khulu'

3) นางอั้ว nang ua 'Miss Nang Ua'

เขาว่าขูลูเทียว $\quad$ เทียบเทียมนางอั่ว
khaw waa khulu thiaw
'they said that Khulu

As we can see from above examples, the word ท้าว thaw 'mister' and นาง nang 'miss' are considered as name titles. The word ท้าว thaw means 'mister' whereas นาง nang pragmatically means 'miss'. In standard Thai, the word นาง nang literally is referred to a lady who already got married but in Isan society this particular word can be used as a name title for a lady in general whether or not she was married.

The word ท้าว thaw and นาง nang, for literary style of composing, they can put after the name of the protagonist as in ขูลูท้าว khulu-thaw which means 'mister Khula' as shown in the following example.

4) ขูลูท้าว khulu-thaw 'mister Khulu'

บัดนี้ จักกล่าวเถิงขูลูท้าว

bat-ni cak klaaw theong khulu thaw kaa-sii baa-baaw

'now $(\oslash)$ will mention Mister Khulu, guy of Kasi

As we can see from example 4, the word ท้าว thaw 'mister' is put after the name ขูลู khulu but it still means 'Mister Khulu'

The strategy of using name title+name+modifier: For this strategy, the writer will put words after the name of the protagonist to clarify a prominent character of the main characters such as how handsome and beautiful he or she is or how lovely they are.

5) นางอั้วเคี่ยม nang-Ua-kiam ' a beautiful Nang Ua'

ค้อมว่าบอระบวนแล้ว

khorm waa bor-ra-buan laew

'when every thing ready

The above example shows that the word เคี่ยม khiam 'beaytiful' is put as a modifier after นางอั้ว nang ua 'nang Ua' which are name title 'miss' and name 'Ua', respectively. The word เคี่ยม khiam which means 'beautiful' is attached to her name 'Ua' in order to show that this protagonist is beautiful.

6) นางอั้วน้อย nang ua norj 'small (lovely) Nang ua'

\section{แต่นั้นนางอั้วน้อย ต้านต่อขูล}

Tae-nan nang-ua-norj taan tor khulu 'at that time lovely NangUa spoke to Khulu'

The word น้อย norj which means 'little' is put after name of the main character นางอั้ว nang ua 'Nang Ua' to elucidate pragmatically that she is a lovely lady.

The strategy of using name+ modifier: For this strategy, the writer just used the name of the main characters without a name title as a head and another word as a modifier to address the character. The following is an example of this strategy.

(7) อั้วเคี่ยมน้อย ua khiam norj 'beautiful and small (lovely) Ua'

\section{อั้วเคี่ยมน้อย งามย้อยดั่งเขียน}

Ua-khiam-norj ngaam jorj dang khian

'a beautiful Ua was beautifu as a painting'

As shown in example 7, it is clear that the word : อั้ว ua 'Ua' functions as a head of address word and เคี่ยมน้อย khiam-norj 'beautiful and small (lovely)' functions as a modifier. It is attached to the name to state that this lady is beautiful and lovely.

\section{Indirect address}

As for the indirect address, there are also four sub-strategies that the writer used them to refer to main characters in the story as follows:

The strategy of using metaphorical words: It was found that this strategy is the strategy that the write preferred using it to others. The following table shows the metaphorical words that used to address the hero, Khulu.

Table I

The metaphorical words used for Khulu

\begin{tabular}{ll}
\hline Metaphorical Words & Meanings \\
\hline แจ่มเจ้า cam caw & 'bright guy' \\
สายคอกู saj khor kuu & 'my necklace' \\
จอมเจ้า corm caw & 'the great guy' \\
จอมใจชาย corm caj chaaj & 'the dearest guy' \\
จอมบุญ corm bun & 'the great merit' \\
ทรงธรรม song tham & 'being in dharma' \\
จอมปรางแก้ว corm prang kaew & 'the great guy of the crystal castle' \\
สายไจอวน saj caj uan & 'my dear heart'
\end{tabular}

If we look closely at Table I, we will find that the meanings of the metaphorical words that used to address the protagonist, Khulu, can be classified semanticaly in different three fields of Khulu's characteristics as follows:

1. Khulu was a well-beloved guy as shown in สายไจอวน saj caj uan 'my dear heart', แจ่มเจ้า cam caw 'bright guy', จอมใจชาย corm caj chaaj 'the dearest guy', and saj khor kuu 'my necklace'.

2. Khulu was the great guy as shown in จอมเจ้า corm caw 'the great guy' and จอมปรางแก้ว corm prang kaew 'the great guy of the crystal castle'.

3. Khulu was a good guy as shown in สายคอกู corm bun 'the great merit' and ทรงธรรม song tham 'being in dharma'. 
It was found that the writer always used the metaphorical words to describe that Khulu was a well-beloved man. There are a lot of words to form this field of meaning. It is because the writer would like to elucidate how much Nang Ua loved Khulu.

The following table shows some metaphorical words that used to address the heroine, Nang Ua.

Table II

The metaphorical words used for Nang Ua

\begin{tabular}{ll}
\hline Metaphorical Words & Meanings \\
\hline สายคออวน| saj khor uan & 'my necklace' \\
สายคอกู saj khor kuu & 'my necklace' \\
แจ่มเจ้า cam caw & 'bright lady' \\
คำจอมศรี sii cam caw & 'bright lady greatness' \\
คำจอมศรี kham corm sii & 'the golden greatness' \\
จอมนาง corm nang & 'the great lady' \\
จอมขวัญ corm khwan & 'sweetheart' \\
สายใจ saj caj & 'my heart' \\
คำแก้ว kham kaew & 'gold and jems' \\
ใจเมือง caj muang & 'heart of city' \\
หน่อเมือง nor muang & 'child of city' \\
ทิพขึนแก้ว thip khin kaew & 'beautiful as an angel' \\
\hline
\end{tabular}

From the Table II, the meanings of the metaphorical words used for the protagonist, Nang Ua, can be classified semanticaly in four fields of Nang Ua's characteristics as follows:

1. Nang Ua was a well-beloved lady as shown in สายคออวน saj khor uan 'my necklace', สายคอกู saj khor kuu 'my necklace', แจ่มเจ้า cam caw 'bright lady', คำจอมศรี sii cam caw 'bright lady greatness', and สายใจ saj caj 'my heart'.

2. Nang Ua was a beautiful lady as shown in ทิพขึ่นแก้ว thip khin kaew 'beautiful as an angel'.

3. Nang Ua was a valuable lady as shown in คำจอมศรี kham corm sii 'the golden greatness' and คำแก้ว kham kaew 'gold and jems'.

4. Nang Ua was an important part of the city as shown in ใจเมือง caj muang 'heart of city' and หน่อเมือง nor muang 'child of city'.

If we compare the field of meaning of the metaphorical words used for Khulu and Nang Ua, we will see that the meaning of being well-beloved is the main strategy to be used mostly for both of them. As a leadership, Khulu was presented as a leadership through many metaphorical words whereas Nang Ua was presented as a beautiful and valuable lady.

The strategy of using pronouns: Based on my data, it was found that for the indirect strategy the writer used pronouns referring to Khulu only. There is no any pronouns used for Nang Ua. The following is a pronoun often used in Khulu-Nang Ua.

8) บา baa 'he'

บาจึ่งเข้า

\section{ศาลาเซาจอด}

baa cing khaw saa-laa saw cort

'he then entered a pavilion to take a rest'

The word บา baa 'he' is a third person singular pronoun used to address a male. It is sometimes followed by a name title ท้าว as in บาท้าว baa thaw 'he'.

The strategy of using name title: In stead using name, only the name title can be used as a word to refer to the protagonist. The followings are the name titles used to address Khulu and Nang Ua. 9) ท้าว thaw 'mister'
นางเหลียวเห็น

nang liaw hen

'Miss (she) saw

(10) นาง nang 'miss'

นางก็สุขเลิศล้ำ

แล่นมาหาท้าว

laen maa haa thaw

(and then) ran to Mister (him)

nang kor suk lert lam naj aat hong luang

'miss (she) was happy in a big hall'

From example 9 and 10, as name titles, it is normal to used these name titles to refer to the main charcters. Based on the context, they occurred, the word ท้าว thaw 'mister' is used to refer to Khulu whereas the word นาง nang 'miss' is selected to refer to Namg Ua. Both of these two name titles mean and function pronouns 'he' and 'she'.

The strategy of using name title + modifier: For this strategy, words used with name title clarify some characteristics of the protagonist as in below examples.

11) นางแพง nang phaeng 'miss beloved'

นางแพงจาเสียงใส สั่งบาคำละห้อย

nang phaeng caa siang saj sang baa kham-la-horj

'beloved lady spoke clearly to say goodbye sadly'

The word แพง phang 'beloved' is put after the name title นาง nang 'miss' to clarify that Nang Ua is a beloved lady of Khulu.

12) นางน้อย nang norj 'little lady'

มาโอมขอ เหนี่ยวเอานางน้อย
maa ohm khor niaw aw nang-norj

to come and propose marriage (and) to drag Nang Ua'

The word น้อย norj 'little' in example 12 which is ued to modify the name title นาง nang 'miss' is referred to Nang Ua. This word metaphorically presents the meaning of cuteness of Nang Ua.

\section{Discussion}

As we can see from the results, it is clear to mention that the strategy of using metaphorical words plays a crucial strategy that the author prefers using it to other strategies. In terms of the field of meaning of the metaphorical words used for Khulu and Nang Ua, we will see that the meaning of being well-beloved is the main strategy to be used mostly for both of them. It is effective strategy because this folk literature is about a tragic love story. The author would like to narrate to the reader how much they loved each other. And because of their true love, they can sacrifice themselves with death for their love. By using this indirect strategy, it was successful for the author to make the story to be real for the reader to understand why they did suicide at the end.

One thing that we can see from addressing main characters in this tragic love story is that the author presents a leadership to the hero, Khulu, through many metaphorical words. It is interesting to study further in a comparison with other love stories of Isan literature if they share the same strategy and why. For the heroine, it is obviously in Isan literature that the heroine is often presented as a beautiful and valuable lady (Punnotok, 1982,1994). And using indirect address of metaphorical words is a good strategy to emphasize this value.

\section{Limitations and Further Research Directions}

This study has some limitations which could be addressed in future. The recommendations for the further research are described as follows:

a. A study could further improve and compare how different strategies are used among main chracters in terms of gender together with other characters opposing the main character (antagonist).

b. A study could be more accurate thereby collecting a much larger data of 
Isan literature.

c. A future study should learn more about semantic field of using metaphorical words to refer to main characters in Isan literatures.

\section{Conclusion}

To conclude, there are different ways that the writer created words to refer to the main character or the protagonist. In Khulu-Nang Ua, there are two main strategies as direct and indirect strategies obviously used. The indirect strategies, especially using metaphorical words, are always used. Both Khulu and Nang Ua were presented as well-beloved to each other. That was why Khulu committed suicide after Nang Ua when he heard that Nang Ua hanged herself on the tree. In terms of word formation or word structure, the writer always modified the name or name title of the protagonist to highlight a prominent characteristics of the character.

\section{References}

Bevington, D. (2019). Romeo and Juliet. Retrieved from https: //bit.ly/ $3 i F 2 \mathrm{kKr}$

Phiuthong, B. (2002). An a analysis of a northeastern version: Khulu Nang$U a$ (Unpublished masters thesis). Ramkhamhaeng University, Bangkok, Thailand.
Prasertsang, P. (2018). Khulu-Nang Ua/Chau Sam Lo: Coincident and non coincident characteristics in socio-Culture of Isan and Thai Khoen people. Retrieved from https://bit.1y/31TCs7o

Punnotok, T. (1982). Reginal literature. Bangkok, Thailand: Odeon Store.

Punnotok, T. (1994). Isan literature. Bangkok, Thailand: Ramkhamhaeng University.

Shakespeare Birthplace Trust. (n.d.). Romeo and Juliet: Synopsis and plot overview of Shakespeare's Romeo and Juliet. Retrieved from https:// bit.1y/2C4feAO

Thamwat, J. (1999). Local literature: Isan-lan chang. Ubon Ratchathani, Thailand: Siritham Offset.

Williamson, K., Johanson, G., Byrne, A., Given, L. M., Kennan, M. A., \& Oliver, G. (2018). The future of information research. In Research methods: Information, systems, and contexts (chap. Amsterdam, Netherlands). Elsevier.

Wisaphan, W. (2006). Wannakhadi kan lakhon. Mahasarakham, Thailand: Aphichat Printing. 